\title{
DEMOCRACY, ANTI-DEMOCRACY, AND THE CANON
}

\author{
Richard H. Pildes*
}

Democracy is the Banquo's ghost of American constitutionalism. Appearing evanescently in vague discussions of processbased theories of judicial review, or in isolated First Amendment cases involving political speech, or in momentary Equal Protection forays into racial redistricting, democracy hovers insistently over the constitutional canon. Yet democracy itself has not been brought onto center stage. From the background, democracy's obligations press upon the canon's principal players-rights, equality, separation of powers, federalism. We endlessly debate which issues should be left to "democratic bodies" and which to judicial review, but with little concern for the prior question of how the law ought to structure the institutions and ground rules of democracy itself. In the conventional constitutional canon, democracy is nearly absent as a systematic focus of study in its own right. If campaign financing is addressed, it is in narrow First Amendment terms of whether "money is speech"-not as part of the broader inquiry necessarily at stake concerning the role of political parties, individual candidates, and "independent" ideological and economic groups in a healthy democracy. If racial redistricting is presented, it is as one more variant of affirmative action - not in the context of competing conceptions of the aims of political representation, or of the general tension between minority interests and majoritarian politics, or of the history of the secret ballot, ${ }^{1}$ literacy tests, poll taxes, and vote dilu-

* Professor of Law, University of Michigan Law School; Visiting Professor of Law, NYU Law School. My assessment of Giles has been greatly influenced by conversations with Rebecca Scott and Sam Issacharoff; this draft further benefitted from exceptionally detailed comments from J. Morgan Kousser and Adam Winkler, as well as the insightful readings of Rick Hills, Larry Kramer, Derrick Bell, Michael Klarman, Daryl Levinson, and Barry Friedman. I am grateful to Marita Etcubanez, for a student paper that introduced me to the historical resources involving Booker $T$. Washington and to Michael Sant'Ambrogio for research assistance.

1. Yes, the secret ballot, which was the subject of intense political struggle in the South and seems there to have been adopted "primarily to purge the electorate of illiter- 
tion, as well as the policies and current Department of Justice enforcement practices under the Voting Rights Act. If the constitutional right to vote is noted, it is only as one example of the fundamental rights strand of Equal Protection law (along with, perhaps, the right to travel or access to the judicial system) - but not as an opening into what institutional configurations of democratic bodies, with what voting electorates, might be best for the myriad functions government now performs. ${ }^{2}$

If sustained attention to democracy itself has been startlingly absent from the constitutional canon, so too has its antithesis: the history in American politics and constitutional law of anti-democracy. For constitutional law played a role in sustaining the blatant manipulations of political institutions that kept America from fully becoming a democracy before $1965 .^{3}$ Recovering this history of the Supreme Court's removal of democracy from the agenda of constitutional law, for most of the 20th century, is one way of bringing democracy to constitutional thought today. In this bleak and unfamiliar saga, there is one key moment, one decisive turning point: the 1903 opinion of Justice Oliver Wendell Holmes in Giles $v$. Harris. ${ }^{4}$ If canonization requires a ready focal point, this is it for (anti-)democracy in American constitutional law. By bringing Giles into the constitutional corpus, we can begin to put democracy itself at the core of constitutional thought, where it belongs.

ates." In fact, the secret ballot did produce sharp declines in voter tumout, particularly among black voters. J. Morgan Kousser, The Shaping of Southern Politics: Suffrage, Restriction, and the Establishment of the One-Party South, 1880-1910 at 53-56 (Yale U. Press, 1974) ("Southern Politics").

2. Even the pathbreaking John Hart Ely, Democracy and Distrust: A Theory of Judicial Review (Harvard U. Press, 1980), employs "democracy" in a thin and instrumental way, as a means of justifying certain judicial interventions, without offering a robust, substantive account of how democracy ought to be structured and conceived. For the now classic statement of this critique, see generally Richard Davies Parker, The Past of Constitutional Theory-And Its Future, 42 Ohio St. L.J. 223 (1981). And with the emphasis on rights and equality that has dominated constitutional writing since then, of which Ronald Dworkin's work is perhaps most emblematic, democracy has receded even further into the background of the contemporary canon.

3. Writing from the vantage point of 1935 about the post-Reconstruction disfranchisement of black voters, W.E.B. Du-Bois said: "In no other civilized and modern land has so great a group of people, most of whom were able to read and write, been allowed so small a voice in their own government." W.E.B. Du-Bois, Black Reconstruction in America 694 (Atheneum, 1992). That remained true until the Voting Rights Act of 1965. In Mississippi, the black voter registration level was $6.7 \%$ on the eve of the Act's passage. See Richard H. Pildes, The Politics of Race, 108 Harv. L. Rev. 1359, 1360 (1995).

4. 189 U.S. 475 (1903). 
Giles has been airbrushed out of the constitutional canon. It is surely one of the most momentous decisions in United States Supreme Court history and one of the most revealing. Yet, as far as I can tell, it receives nary a mention in four of the leading Constitutional Law casebooks. ${ }^{3}$ A fifth, the most historically oriented, notices the case but in an uncharacteristically legalistic footnote that hardly conveys the stakes. ${ }^{6}$ Professor Tribe's magisterial treatise does not cite it. ${ }^{7}$ Giles permits the virtual elimination of black citizens from political participation in the South. Yet while extensive attention is devoted to judicial validation of separate but equal segregation, none is devoted to this. Every law student knows of Plessy v. Ferguson; ${ }^{8}$ virtually none know of Giles. Many well-established constitutional scholars I have spoken with have not heard of the case. ${ }^{9}$ Even among some academics seeking to make race a more central feature of the constitutional canon, the momentous case and context are not known. ${ }^{10}$ This is not surprising, for it merely confirms how powerful canonization, or its absence, can be. Even the Soviets

5. See Daniel A. Farber, William N. Eskridge, Jr., and Philip P. Frickey, Constitutional Law: Themes for the Constitution's Third Century (West, 2d ed. 1998); Gerald Gunther and Kathleen M. Sullivan, Constitutional Law (Foundation Press, 13th ed. 1997); William B. Lockhart, Yale Kamisar, Jesse H. Choper, Steven H. Shiffrin, and Richard H. Fallon, Constitutional Law Cases-Comments-Questions, American Casebook Series (West, 8th ed. 1996); Geoffrey R. Stone, Louis M. Seidman, Cass R. Sunstein, and Mark V. Tushnet, Constitutional Law (Aspen, 3d ed. 1996). For a revealing history of how the Dowling-Gunther-Sullivan casebook has treated issues of democracy from 1937 on, see generally Pamela S. Karlan, Constitutional Law, the Political Process, and the Bondage of Discipline, 32 Loy. L.A. L. Rev. 1185 (1999).

6. See Paul Brest and Sanford Levinson, Processes of Constitutional Decisionmaking Cases and Materials 253 n.30 (Little, Brown and Co., 3d ed. 1992) (describing holding as that an action in equity could not be maintained to require supervision of voting in Montgomery County). The forthcoming next edition does provide a oneparagraph textual discussion of Giles, which must be considered a breakthrough of sorts.

7. Laurence H. Tribe, American Constitutional Law (Foundation Press, $2 \mathrm{~d}$ ed. 1988), and Laurence H. Tribe, 1 American Constitutional Law, (Foundation Press, 3d ed. 2000). I am relying on the table of cases to these volumes.

8. 163 U.S. 537 (1896).

9. The case is appreciated appropriately in Owen Fiss's contribution to the Holmes Devise. Owen M. Fiss, History of the Supreme Court of the United States: The Troubled Beginnings of the Modern State, 1888-1910 at 373 (Macmillan, 1971).

10. Without meaning this to be critical, I have in mind here as exemplary Fran Ansley's recent essay, Recognizing Race in the American Legal Canon, in S. Levinson, ed., (forthcoming). The case is discussed in Derrick Bell, Race, Racism, and American Law 45-46, 112, 177, 189 n.14 (Little, Brown \& Co., 3d ed. 1992), Bell views Holmes' political judgment about the limits of the Court's power as "the truth." 
could admire this success at obscuring all traces of a prior political regime. ${ }^{11}$

Yet historically, the context of Giles is as dramatic as any in American political and constitutional history. ${ }^{12}$ Jurisprudentially, the opinion weds legalism with realpolitik into one of the most fascinatingly repellant analyses in the Court's history. And doctrinally, the reverberations of Giles resound throughout the century; for notwithstanding the Fourteenth and Fifteenth Amendments, Giles carves out from them the category of "political rights" and holds such rights unenforceable. ${ }^{13}$ And so they were, until Baker v. Carr, ${ }^{14}$ sixty years later, with Giles enlisted by Justices like Felix Frankfurter in support of constitutional law's insistence that democracy remain off stage. ${ }^{15}$

11. This erasure was literally true in some contexts. Thus, the official compiler in Georgia of the state's legislative manual, decided after Reconstruction ended to omit black lawmakers from the biographical sketches in the volume. It would be absurd, he wrote, to record "the lives of men who were but yesterday our slaves, and whose past careers, probably, embraced such menial occupations as boot-blacking, shaving, tablewaiting, and the like." See Eric Foner, Freedom's Lawmakers: A Directory of Black Officeholders During Reconstruction xii (Louisiana State U. Press, rev. ed. 1966).

12. In the odd context of an appeal from a murder conviction, the disfranchising provisions of the 1890 Mississippi Constitution had been brought to the Court in Williams v. Mississippi, 170 U.S. 213 (1898). Because jurors had to be qualified electors, a black defendant challenged his conviction by an all-white jury on the ground that the suffrage provisions in the new state constitution violated the federal Constitution. The Court took this as a facial challenge to the provisions and rejected them in not nearly as direct a confrontation with the issue of disfranchisement as Giles soon posed. Disfranchising politicians did not see Williams as the carte blanche that Giles would soon offer; on the contrary, Williams suggested that the litigation had failed for want of proof of racially-discriminatory effects. Disfranchisers feared that Williams implied that adequate proof of such effects would make the emerging Southern electoral laws and administrative practices unconstitutional. See J. Morgan Kousser, Colorblind Injustice 322 (U. of North Carolina Press, 1999). Williams' lawyer, Cornelius J. Jones, was also pursuing congressional relief against Mississippi's 1890 Constitution by asking Congress to unseat representatives elected under that Constitution. Id. at 321.

13. Lest this sound familiar, Giles does not involve the republican form of government clause nor does it cite Luther $v$. Borden for its holding.

14. 369 U.S. 186 (1962).

15. See, e.g., Colegrove v. Green, 328 U.S. 549, 552 (1946) (Frankfurter, J., announcing the judgment of the Court) (plurality opinion) (citing Giles). The Court did hold unconstitutional the grandfather clauses, which exempted from newly-imposed suffrage restrictions, for example, those eligible to vote as of 1866 and their lineal descendants. Guinn v. United States, 238 U.S. 347 (1915). But even their proponents thought these clauses almost transparently unconstitutional; in this context, the Court was in alignment with the national executive branch, which prosecuted the action; the Court could invalidate these clauses based on "the mere statement of the text" itself, id. at 364, which proclaimed its racially discriminatory purpose, rather than having to address an asapplied challenge or a fact-based claim of discriminatory administration; and perhaps most importantly, the Court could invalidate these provisions on their face without having to monitor actual registration processes (as a practical matter, Guinn's principal ef fect was not to enfranchise black voters, but to extend the distranchisement of white voters who could not otherwise comply with the new suffrage restrictions). In addition, the 
Consider, first, the historical context that brought before the Supreme Court Jackson Giles, a literate black man and Republican-party activist in a federal patronage job employed as the janitor in Montgomery, Alabama's federal courthouse. ${ }^{16}$ Giles was President of an organization called the Colored Men's Suffrage Association; he had registered and voted in Montgomery from 1871 to 1901 . In the aftermath of the Civil War, black suffrage had been "the most radical element of Congressional Reconstruction." 17 With the passage of the Reconstruction Acts of 1867 , the meaning of emancipation came to include-crucially - political participation and the democratization of America. The Acts required the defeated Southern States to adopt new constitutions, acceptable to Congress, as a condition for reentry to the Union. The Acts also required that eligibility to vote for delegates to these State constitutional conventions not be denied "by reason of race or color," and that the resulting constitutions guarantee racially non-discriminatory suffrage. The result was that in the next elections, nearly half the voters in the South were black; indeed, black voters at that moment con-

Court struck down the whites-only primary in a quadrology of cases from Texas spanning 26 years, commencing with Nixon v. Herndon, 273 U.S. 536 (1927), and concluding with Terry v. Adams, 345 U.S. 461 (1953). These were more significant decisions, though their practical effect was mostly to force Southern white-primary states toward more aggressive use of previous restrictions that had lain dormant for years, such as literacy tests, but here too the Court could resolve the issue on the face of the relevant provisions-in Herndon, Texas law provided that "in no event shall a negro be eligible to participate in a Democratic party primary"-and hold those provisions unconstitutional, without any need for more extensive judicial oversight. And in some states, such as Mississippi, the legislature then mandated that voters could vote in party primaries only if they were "in accord with" party principles; the State Democratic Party executive committee then defined those principles to include opposition to federal antilynching laws, anti-poll tax laws, and the Fair Employment Practices Commission. John Ditmer, Local People: The Struggle For Civil Rights in Mississippi 26 (U. of Illinois Press, 1994). With respect to the continuing influence of Giles, the Nixon opinion expressed an obligation to distinguish Giles, and while the latter was not mentioned in Guinn, the Court did feel obligated in the follow-up case to Guinn also to distinguish Giles. See generally Lane v. Wilson, 307 U.S. 268 (1939). Justice Frankfurter, who wrote Lane, then drew on Giles a few years later in Colegrove to help justify keeping federal courts out of the truly major challenge to frozen democratic structures that the malapportionment cases raised.

16. See Kousser, Colorblind Injustice at 322 (cited in note 12). Federal employment might have insulated Giles somewhat from economic pressure and enabled him to serve as plaintiff in a series of cases. For an eye-opening account of the totalistic and brutally successful economic warfare later waged on similar black activists in Mississippi who sought to vote or to enforce Brown v. Board of Education, see the Bancroft Prizewinning book, Dittmer, Local People 41-50 (cited in note 15).

17. Eric Foner, Reconstruction: America's Unfinished Revolution, $1863-1877$ at 278 (Harper \& Row, 1988). 
stituted a majority of the electorate in states like Alabama, Florida, Louisiana, Mississippi, and South Carolina (initially, thousands of whites were ineligible because of their roles in the Confederacy while other whites refused to participate). ${ }^{18}$ Economic intimidation was rampant and often immediate; in Giles' home town, for example, an employer noticed one of his laborers in line to vote and fired him on the spot. ${ }^{19}$ Yet black voter turnout was stunningly high, approaching 90 percent in many elections. ${ }^{20}$ As Eric Foner puts it, "[r]arely has a community invested so many hopes in politics as did blacks during Radical Reconstruction." 21 Jackson Giles apparently shared in that hope. The Fifteenth Amendment, adopted in 1870, gave these hopes constitutional expression and, no doubt Giles thought, constitutional security.

Black (male) political participation remained extraordinary high long after federal military forces were withdrawn from the South in 1877. In 1880, two-thirds of adult black men voted in the Presidential election; even in the 1890s, half of black men still voted in key governor's races in Southern states. ${ }^{22}$ Black officials also held political offices (around 2,000 in number) at every level in the South, from state Supreme Courts, to the U.S. Senate, down to the county and local level..$^{23}$ Indeed, the number

18. See Leon Litwack, Been in the Storm So Long: The Aftermath of Slavery 546 (Knopf, 1979). Amnesty bills were soon adopted, and Alabama and Florida did not long retain statewide majority-black electorates. But in Mississippi, for example, on the eve of the 1890 Constitutional Convention, there were 189,884 registered black voters compared to 118,890 registered whites. See Morton Stavis, A Century of Struggle For Black Enfranchisement in Mississippi: From the Civil War to the Congressional Challenge of 1965-and Beyond, 57 Miss. L.J. 591, 603 (1987). By 1892, only 68,127 white voters qualified as eligible and a mere 8,615 black voters. Id. at 605 .

19. See id. at 556.

20. Foner, Reconstruction at 291 (cited in note 17).

21. Id.

22. See J. Morgan Kousser, The Voting Rights Act and the Two Reconstructions, in Bemard Grofman and Chandler Davidson, eds., Controversies in Minority Voting: The Voting Rights Act in Perspective 135, 141 (Brookings, 1992) ("The Voting Rights Act"). As late as 1898 , black-white political coalitions controlled electoral outcomes in places like Grimes County, Texas. See Lawrence C. Goodwyn, Populist Dreams and Negro Rights: East Texas as a Case Study, 76 Am. Hist. Rev. 1435, 1439-43 (1971).

23. See Foner, Reconstruction at 537-39 (cited in note 17); see also Foner, Freedom's Lawmakers xi (cited in note 11). It is no accident that Fort Bend County, Texas was home to the Jaybird Association, the all-white, private political organization eventually to be held unconstitutional by the United States Supreme Court in Terry v. Adams, 345 U.S. 461 (1953). From 1868-1888, blacks outnumbered whites four to one in the county, and black officials held numerous political offices. See Darlene Clark Hine, Black Victory: The Rise and Fall of the White Primary in Texas 33-34 (KTO Press, 1979). The Jaybirds arose as the private organizational arm of white supremacy's political return to Fort Bend. 
of Southern black legislators elected in 1872 was not matched again until the 1990s (in the wake of Thornburg $v$. Gingles ${ }^{24}$ ), and, though black officeholding declined sharply by 1880 , even that much-reduced number was not again reached until 1972, seven years after the Voting Rights Act. ${ }^{25}$

Yet the forces of elite, conservative, white political control, through the organized vehicle of the Democratic Party, slowly recovered political power through a series of increasingly effective tactics: outright violence and intimidation, including in the worst single day of carnage, the massacre of at least 105 surrendering blacks at the courthouse in Colfax, Louisiana ${ }^{26}$ (the focus of initially successful federal prosecutions soon overturned in United States v. Cruikshank ${ }^{27}$ ); fraudulent manipulation of ballots; racial gerrymandering of election districts and other dilutive structural devices; and statutory suffrage restrictions that greatly reduced the black and poor-white electorate. For those who mistakenly believe in the inevitability of white supremacy in this period, the key word here is "slowly"; it took several years of the self-conscious construction and organized mobilization of a militarized white supremacy, often against a divided white business community willing to accommodate black political participation for the sake of stability, to enable white "redemption" of the South. ${ }^{28}$ This step-by-step process eventually culminated in sufficient white control to produce new constitutional conventions, or suffrage-restricting constitutional amendments through referenda, in every former Confederate state, starting with Mississippi in 1890 and ending with Georgia in $1908 .^{29}$ The avowed purpose of these new constitutions was to restore white suprem-

24. 478 U.S. 30 (1986)

25. These figures are put together for the first time in Kousser, Colorblind Injustice, at 19 (cited in note 12), and they involve blacks elected to Southern state legislatures or the United States Congress.

26. Described in horrifying detail in Ted Tunnell, Crucible of Reconstruction: War, Radicalism, and Race in Louisiana, 1862-1877 at 173-218 (Louisiana State U. Press, 1984).

27. 92 U.S. 542 (1875)

28. The specific details of this process are vividly portrayed for New Orleans in Lawrence N. Powell, "The Battle of Canal Street: An Upper-Class Dream of Power and Preferment," presented at the annual meeting of the Organization of American Historians, Toronto, Canada, April 25, 1999 (draft on file with author).

29. The relevant dates are Mississippi, 1890 (convention); South Carolina, 1895 (convention); Louisiana, 1898 (convention); North Carolina, 1900 (amendment); Alabama, 1901 (convention); Virginia, 1902 (convention); Texas, 1902 (amendment); Georgia, 1908 (amendment). Constitutional disfranchisement was the capstone to the elimination of black political participation, and while it was preceded and facilitated by earlier statutory and other disfranchisement techniques, it cast disfranchisement into the most endurable and symbolically significant legal form. 
acy, but that was not their only aim. For the Framers of disfranchisement were typically the most conservative, large landowning, wealthy faction of the Democratic Party, who were also seeking to entrench their partisan power and fend off challenges from Republicans, Populists, and other third parties, as well as from the more populist wings of the Democratic Party. While pledging not to disfranchise any whites, they advocated provisions that would remove the less educated, less organized, more impoverished whites from the electorate as well-and that would ensure one-party, Democratic rule, which is precisely what happened from this moment forward through most of the 20th century in the South. ${ }^{30}$

The white-supremacy purposes of these new constitutions were not disguised (though the concomitant aim of reducing populist white political influence was). As expressed by the President of the Alabama Convention whose handiwork Jackson Giles would soon challenge, "what is it that we want to do? Why it is within the limits imposed by the Federal Constitution, to establish white supremacy in this State.","31 The resulting 1901 constitution of Alabama offered "the most elaborate suffrage requirements that have ever been in force in the United States;", going on for pages, they "contained almost every qualification for voting ever devised by the mind of man," exception of a religious qualification: racially-gerrymandered criminal disfranchisement provisions, lengthy residency re-

30. Kousser's brilliant book documents this thesis in superb detail. See Kousser, Southern Politics at 238-265 (cited in note 1). Studies of individual states have concluded that, in some, more whites than blacks turned out to have been disfranchised after grandfather provisions were eliminated or held unconstitutional. See, e.g., Malcolm Cook Mcmillan, Constitutional Development in Alabama, 1798-1901: A Study in Politics, the Negro, and Sectionalism 357, 359 (U. of North Carolina Press reprint, 1978) ("Constitutional requirements, which supposedly discriminated against 'Negro characteristics' rather than the Negro race, proved to be a web in which more whites than Negroes were caught.").

31. Quoted in Hunter v. Underwood, 471 U.S. 222, 229 (1985). The most brazen leader of black disfranchisement was South Carolina's United States Senator, Benjamin R. "Pitchfork Ben" Tillman, who proclaimed on the floor of the U.S. Senate: "We have done our level best. We have scratched our heads to find out how we could eliminate every last one of them. We stuffed ballot boxes. We shot them. We are not ashamed of it." (quoted in Chandler Davidson and Bernard Grofman, eds., Quiet Revolution in the South 194 (Princeton U. Press, 1994) ("Quiet Revolution")).

32. Kirk H. Porter, A History of Suffrage in the United States 213 (Greenwood Press, 1918). On the eve of the Voting Rights Act, only 19 percent of the black votingage population was registered in Alabama, compared to 69 percent of whites. As a result of the Act and popular mobilization, by 1967 , a mere three years later, $52 \%$ of the black voting-age population was registered. Davidson and Grofman, Quiet Revolution at 38-39 (cited in note 31 ).

33. Mcmillan, Constitutional Development in Alabama at 359 (cited in note 30). 
quirements, a cumulative poll tax of $\$ 1.50$, along with temporary clauses requiring good character but with grandfather provisions for ex-soldiers and their lineal descendants. ${ }^{34}$ This was particularly ironic in Alabama, a state that had long had the most liberal suffrage rules in the nation: universal white manhood suffrage since its admission in 1819 (along with the secret ballot, mandatory population-based apportionment in both houses every six years, relatively easy override of gubernatorial vetoes, and similarly populist provisions) and universal manhood suffrage since 1868 .

The effect of these disenfranchising constitutions throughout the South, combined with statutory suffrage restrictions, was immediate and devastating. In Louisiana, in 1896 there had been 130,334 black voters on the registration rolls and around the same number of white voters (the state's population was about 50 percent white and black); by 1900, two years after the new constitution, registered black voters numbered a mere $5,320{ }^{36}$ By 1910, 730 registered black voters were left (less than 0.5 percent of eligible black men). In 27 of the state's 60 parishes, not a single black voter was registered any longer; in 9 more parishes, only one black voter was. In South Carolina, black legislators had been the majority in the lower house during Reconstruction; by 1896 , the entire state had only 5,500 black voters registered. ${ }^{3}$ In Alabama, in 1900 there were 181,471 eligible black voters, but only 3,000 were registered after the new

34. The Constitution had a bifurcated structure: before 1903 , a temporary registration plan permitted registration for life, subject to compliance with residency, age, and poll-tax obligations, of (1) soldiers or sailors in various wars, including the Civil War, and their descendants, or (2) those of "good character" who "understood" the duties of citizenship. After 1903, any registration had to take place under the full panoply of restrictions than then attached.

35. J. Mills Thornton III, Politics and Power in a Slave Society: Alabama, 1800-1860 at 12-13 (Louisiana State U. Press, 1978); Mcmillan, Constitutional Development in Alabama at 359 (cited in note 30 ).

36. See John Hope Franklin and Alfred A. Moss, Jr., From Slavery to Freedom: A History of Negro Americans 237 (Knopf, 6th ed. 1988). These are official registration figures, which are considered inflated, probably to make ballot-box stuffing less visible; in some parishes, over $100 \%$ of the voting-age males were purportedly registered. See, e.g., Kousser, Southern Politics at 163 (cited in note 1) (recording white-male voter registration rate statewide at $103.2 \%$ on Jan. 1,1897 ). Whatever the absolute registration figures, there is agreement that the post-suffrage restriction registration rates plummeted, with black registration virtually disappearing. Thus, Kousser reports the following data on percentages of Jan. 1: 1) 1896: $96.3 \%(w) ; 93.0 \%(b) ; 2) 1897: 103.2 \%(w) ; 95.6 \%$ (b); 3) $1898: 46.6 \%$ (w); $9.5 \%$ (b); 4) $1902: 58.9 \%$ (w); $2.9 \%$ (b); 5) $1904: 52.5 \%$ (w); $1.1 \%$ (b). By 1898 , new registration laws had gone into effect; by 1902 , the new state constitution. Id. at 163 .

37. See Davidson and Grofman, Quiet Revolution at 192, 194 (cited in note 31). 
constitutional provisions took effect. ${ }^{38}$ In Virginia, there was a $100 \%$ drop-in other words, to zero-in estimated black voter turnout between the Presidential elections of 1900 and $1904{ }^{39}$ North Carolina managed the same complete elimination of black voter turnout over an eight-year period, between the Presidential elections of 1896 and $1904 .^{40}$ This was the legal situation Giles sought to challenge in the only way left, through constitutional litigation.

Where would the resources, the organizational support, and the professional expertise necessary to undertake litigation of this sort come from? Even these aspects of Giles are full of surprise, for as historians discovered during the 1950s, the financing and representation for the Giles litigation was secretly arranged by none other than Booker T. Washington: the figure whose public persona exemplified, not confrontation, but accommodation to segregation and disfranchisement. ${ }^{41}$ Washington is best known for his 1895 Atlanta Compromise address, in which he became the leading black spokesperson for asserting that blacks should accept segregation and cease engaging in "political agitation" if whites were willing to provide opportunities for economic progress - the kind of progress Washington's vocational training school, the Tuskegee Institute, defined. These positions earned Washington access to major financial donors and enabled him to become the most politically influential black power broker the country had known. During disfranchisement, Washington favored property and educational restrictions, but pleaded with state constitutional conventions to apply them equally across races; yet when these conventions adopted "grandfather clauses" designed to maintain whites on the rolls, Washington refused in public to argue against ratification. While longtime black voters were being disenfranchised, Washington's home county in Alabama awarded him a lifetime voting certificate.

Yet despite this carefully cultivated public mask of ingratiation, behind the scenes Washington directed and raised funds for lawsuits that challenged Jim Crow: against railroad segregation,

38. Franklin and Moss, From Slavery to Freedom at 237 (cited in note 36). See Mcmillan, Constitutional Development in Alabama at 352 (cited in note 30) (reporting that there were 181,315 registered black voters in 1900, 2,980 in 1903, and 3,742 in 1908).

39. See Kousser, Southern Politics at 241 (cited in note 1).

40. See id.

41. The facts about Washington in these paragraphs were first presented by the great civil-rights scholar, August Meier, in Toward a Reinterpretation of Booker $T$. Washington, 23 J. So. History 220 (1957). A fuller treatment was then developed in Louis R. Harlan, The Secret Life of Booker T. Washington, 37 J. So. History 393 (1971). 
exclusion of blacks from jury pools, and other state discriminatory practices. Washington turns out to have been the principal mover behind the Giles litigation, after having failed first with disfranchisement litigation in Louisiana. Writing in code and swearing his contacts to secrecy lest his political viability with whites, including Northern contributors, be destroyed, Washington chose and paid for his friend and personal lawyer, Wilford H. Smith of New York City, to bring the Giles litigation. He had hoped that the local federal district judge, a southern conservative whom Washington himself had persuaded President Theodore Roosevelt to appoint, would be favorable. But he was not, and Washington pressed Giles to the U.S. Supreme Court. Giles reveals Washington, not as the well-known accommodationist, and not even merely as an ironic example of DuBois' "double consciousness, ${ }^{, 42}$ but as living out a split life in a way not uncommon for other black figures before the modern civil-rights era. $^{43}$

\section{III}

Holmes' opinion for the 6-3 divided Court displays a similar dual personality. Exclusion from the canon cannot be reasons for reasons of length, for Holmes briskly dismissed the case in a terse eleven paragraphs. Giles sought an injunction, on behalf of himself and more than 5,000 similarly situated black voters in Montgomery county, requiring that registration officials enroll him and all other qualified black voters. With typical perverse delight, Holmes stared these claims in their face and represented them starkly: "The white men generally are registered for good under the easy test and the black men are likely to be kept out in the future as in the past. This refusal to register the blacks was part of a general scheme to disfranchise them ..." Technical grounds might have enabled the Court to bypass the merits, ${ }^{44}$ but Holmes raced on to embrace an ultimate confronta-

42. At the very time Washington was secretly financing the Giles litigation, DuBois was leading the charge against Washington, devoting an entire chapter to a critique of Washington's advocacy of "submission and silence as to civil and political rights." W.E.B. Du-Bois, The Souls of Black Folk 36-51 (Penguin, 1989) (originally published 1903).

43. For an intriguing example from the literary world, see Henry Louis Gates, Jr., $A$ Fragmented Man: George Schuyler and the Claims of Race, N.Y. Times, Book Review p. 31 (Sept. 20, 1992).

44. Before reaching the merits, Holmes found the claim was not moot, that the complaint did allege the requisite amount in controversy (then $\$ 2,000$ ), and that state constitutions were included in the relevant federal jurisdictional statutes despite the fact 
tion, for in his words, "we are dealing with a new and extraordinary situation, and we are unwilling to stop short of the final considerations which seem to us to dispose of the case."

As the first such "final consideration," there then follows the most legally disingenuous analysis in the pages of the U.S. Reports. As Holmes noted, the complaint alleged that the "whole registration scheme of the Alabama constitution is a fraud upon the Constitution of the United States..." But in that case, Holmes responded, "how can we make the court a party to the unlawful scheme by accepting it and adding another voter to its fraudulent lists?" Anticipating Joseph Heller, Holmes concluded that the very wrong Giles complained of made impossible the relief he sought: "If we accept the plaintiff's allegations for the purposes of his case, he cannot complain."

Did Holmes actually believe this? It seems unlikely. For in turning to its second "final" consideration, his opinion stunningly shifts from tortured legalisms to brutal political "realisms." Holmes now suggests that, beneath the doctrinal resolution lurks the fear of Supreme Court impotence: any judicial order, says Holmes, "would be an empty form." Giles' complaint, Holmes baldly states, is "that the great mass of the white population intends to keep the blacks from voting." But from this it follows, he asserts, that if "the conspiracy and the intent exist, a name on a piece of paper will not defeat them." For a judicial order to be effective, the Court would have to "be prepared to supervise the voting..." In the early part of this century, such a conception of the Court's reach was inconceivable, at least to the Justices involved. ${ }^{45}$ No doubt Holmes, in particular, viewed the complaint as an invitation for courts, in essence, to re-initiate Reconstruction, or perhaps even the Civil War.

The Court transformed this resistance into the sweeping doctrinal principle that equity cannot enforce "political rights." Thus, Holmes concluded, relief "from a great political wrong, if done, as alleged, by the people of a state and the State itself, must be given by them or by the legislative and political department of the United States." Holmes had every reason to know

that those statutes refer only to acting under color of state "statute, ordinance, regulation, custom, or usage."

45. This is confirmed from outside the opinion itself by the unusual report, after the case was handed down, that an unnamed Justice had asserted "that the legitimate outcome of the power [Giles asked the Court to assume] would be that the court of equity would take charge of the State government and administer it, which is an unheard of proposition." N.Y. Daily Tribune (April 28, 1903). 
this would not be forthcoming, given the political context at the time-indeed, it is the very fear or recognition that any Court order would not be supported by other branches of the national government that underlies the Court's own self-abnegation. $\mathrm{Na}$ tional political reaction to Southern disfranchisement was quiet for many reasons, including that the federal government was seeking to restrict suffrage in newly acquired territories, such as the Philippines and Puerto Rico, and territories it effectively controlled, such as $\mathrm{Cuba}^{46}$ (the constitutional struggle over U.S. expansion is another untold, closely related story in the conventional canon ${ }^{47}$ ).

Giles perhaps confirms the theory that "conformity of the law to the wishes of the dominant power in the community was the fundamental tenet of [Holmes'] legal theory.," ${ }^{48}$ It supports David Luban's view that Holmes "view[ed] electoral majorities as unanswerable military victors[.]" ${ }^{199}$ And it might reflect a resigned moral relativism that some attribute to Holmes's experience fighting for the North in the Civil War, from which Holmes drew the lesson that "[d]eep-seated preferences [could] not be argued about, ${ }^{50}$ and that a judge must never "forget[ ] that what seem to him to be first principles are believed by half his fellow men to be wrong."

46. See Michael H. Hunt, Ideology and U.S. Foreign Policy 80-91 (1987); see also Mcmillan, Constitutional Development in Alabama at 290-91 (cited in note 30). In highvisibility public forums, the most prominent Reconstruction historian of the time, Columbia University's racist William A. Dunning, directly expressed this linkage between domestic and foreign policy regarding race and democracy. Arguing against Reconstruction and for the idea that post-slavery social order "must in essence express the same fact of racial inequality" as slavery itself, he wrote chillingly: "The progress in the acceptance of this idea in the North has measured the progress in the South of the undoing of reconstruction. In view of the questions which have been raised by our lately established relations with other races, it seems most improbable that the historian will soon, or ever, have to record a reversal of the conditions which this process has established." William A. Dunning, The Undoing of Reconstruction, LXXXVIII, The Atlantic Monthly 437, 449 (Oct. 1901). The editors of the Atlantic, in a tone somewhere between sardonic and ironic, remarked, "If the stronger and cleverer race is free to impose its will upon "newcaught, sullen peoples' on the other side of the globe, why not in South Carolina and Mississippi?" Id. at 435. The Republican Party, led by McKinley, who focused on the pursuit of material prosperity, including through Northern investments in the South, did not want that pursuit deterred by a focus on "Negro rights."

47. See Sanford Levinson, 17 Const. Comm. 241 (2000).

48. Gary J. Aichele, Oliver Wendell Holmes, Jr.: Soldier, Scholar, Judge 145 (Twayne Pub., 1989).

49. David Luban, Justice Holmes and the Metaphysics of Judicial Restraint, 44 Duke L.J. 449, 515 (1994).

50. Oliver Wendell Holmes, Jr., Natural Law, 32 Harv. L. Rev. 40, 41 (1918).

51. Oliver Wendell Holmes, Jr., Law and the Court (1913), in Richard A. Posner, ed., The Essential Holmes 147 (U. of Chicago Press, 1992). See Eben Moglen, Holmes's Legacy and the New Constitutional History, 108 Harv. L. Rev. 2027, 2039-40, 2043-44 
The constitutional legitimation of massive disfranchisement did not quite end with Giles v. Harris. For the committed Giles (and his sponsors), took at face value Holmes' intimation elsewhere in the opinion that, while equity could not right political wrongs, damages might be available to individuals whose constitutional rights had been violated. In response, Giles brought follow-up actions for both damages and mandamus. One can almost imagine the pleasure with which the Alabama Supreme Court, no doubt more than content to follow Holmes' lead, invoked his "logic" to toss aside these actions too: it held that (1) either Giles was right, which meant that the registrars had no federal constitutional authority to register him at all, in which case "their refusal to do so cannot be made the predicate for a recovery of damages against them;" or (2) the registrars did have such authority, in which case they had legal immunity for their decisions. In Giles v. Teasley, the U.S. Supreme Court affirmed, holding that adequate and independent state-law grounds insulated the Alabama Supreme Court decision from review.

Giles also illustrates dialogic exchange between Court and Congress, although in a more perverse form than contemporary "constitutional conversationalists" have in mind. From 1869 to 1900 , the House of Representatives used its constitutional power under the "Qualifications Clause" ${ }^{52}$ to set aside election results in over 30 cases from Southern states in which the House Elections Committee concluded that black voters had been excluded due to fraud, violence, or intimidation. ${ }^{53}$ In some cases, the House not only voided the result and required a new election, but, as in an 1880 case from Mississippi, ordered a black candidate seated who, according to state officials, had been defeated by his white opponent. In the last 20 years of the 19 th century, the House 26 times ordered Southern Republicans or Populist congressmen seated because they had lost elections due to fraud. ${ }^{54}$ Importantly, the House concluded that its constitutional powers allowed it to override state-law rulings on the operation and effect of state election laws. The grounds on which the

(1995) (suggesting the unexamined importance of the Civil War experience to the Court's social conceptions).

52. U.S. Const., Art I, $\S 5$, cl. 1 provides: "Each House shall be the Judge of Elections, Returns and Qualifications of its own Members."

53. The information in this paragraph is drawn from the comprehensive and superb study in Stavis, 57 Miss. L.J. (cited in note 18). The cases overturning election results are collected id. at 627 n.156.

54. Kousser, Southern Politics at 263 (cited in note 1) (including cases from 1880 to $1901)$. 
House acted included not just electoral fraud and violence-and not just violence at the actual polls, but a pre-election atmosphere of violence, terrorism, or intimidation ${ }^{53}$-but also, importantly, that state laws such as registration statutes violated the Constitution. Applying these principles, the House overturned congressional elections in this period from Alabama, Georgia, Mississippi, South Carolina, North Carolina, Texas, Virginia, Florida, Louisiana. Thus, the House was aggressively wielding its power to enforce the Fifteenth Amendment throughout this period. As late as 1896 , it remained virtually undisputed in the House that it had the power to conclude, in the context of judging contested elections, that state registration statutes were unconstitutional. ${ }^{56}$

But by the mid-1890s, congressional enforcement of the Fifteenth Amendment began to abate. Although the House still overturned individual election results from Southern states as late as $1900,{ }^{7}$ by 1896 the House began making it clear that it would not act on challenges to the emerging disfranchising constitutions. ${ }^{58}$ The "coup de grace" ${ }^{\text {"59 }}$ was Congress' decision-one month after Giles v. Teasley came down-in the 1904 election challenge in Dantzler v. Lever. With Congress now clearly forced to center stage by the Court's abdication in Giles, Congress in its own disingenous act shuttled responsibility back to the Court. In the 1902 House elections, Asbury Lever had defeated Alexander Dantzler in South Carolina's Seventh District. Dantzler's challenge claimed Lever's victory was illegitimate because South Carolina's new disfranchising constitution violated the Reconstruction Act of 1868 . He asserted that "thousands of colored voters" had been disfranchised under South Carolina's new constitution, in violation of both the 1868 Act and the fed-

55. This was particularly important in Louisiana, which was in a state of virtual Civil War from the 1870 s until 1896, including the worst single-day massacre in Reconstruction history, the Colfax courthouse slaughter, which produced the Supreme Court's notorious decision in United States v. Cruikshank, 92 U.S. 542 (1876), in which the Court held the resulting criminal indictments unconstitutional on the ground that the federal government had no power to reach private racial violence. For a powerful account of these events, see Tunnell, Crucible of Reconstruction at 173-218 (cited in note 26).

56. Stavis, 57 Miss. L.J. at 633 n.176 (cited in note 18).

57. Id. at 627 n.156.

58. This stance was of a piece with Congress' repeal of much of the Reconstruction legislation, which a committee report celebrated by stating: "[let] every trace of the reconstruction measures be wiped from the statute books; let the States of this great Union understand that the elections are in their own hands; and if there be fraud, coercion, or force used they will be the first to feel it." H.R. Rep. No.18, 53d Cong., 1st Sess. 7 (1893), quoted in United States v. Classic, 313 U.S. 299, 335 (1941).

59. Stavis, 57 Miss. L.J. at 637 (cited in note 18). 
eral constitution. But in a firm volte face that relinquished all the powers the House had built up over the last 30 years, the House Committee on Elections confirmed Lever's victory. The Committee declined "to put on record its opinion" of Dantzler's constitutional claim:

However desirable it may be for a legislative body to retain control of the decision as to the election and qualification of its members, it is quite certain that a legislative body is not the ideal body to pass judicially upon the constitutionality of the enactments of other bodies. We have in this country a proper forum for the decision of constitutional and other judicial questions. If any citizen of South Carolina who was entitled to vote under the constitution of that State in 1868 is now deprived by the provisions of the present constitution, he has the right to tender himself for registration and for voting, and in case his right is denied, to bring suit in a proper court for the purpose of enforcing his right or recovering damages for its denial.

That suit can be carried by him, if necessary, to the Supreme Court of the United States. If the United States Supreme Court shall declare in such case that the "fundamental conditions" in the reconstruction acts were valid and constitutional and that the State constitutions are in violation of those acts, and hence invalid and unconstitutional, every State will be compelled to immediately bow in submission to the decision. The decision of the Supreme Court would be binding and would be a positive declaration of the law of the land which could not be denied or challenged.

On the contrary, the decision of the House of Representatives upon this grave judicial question would not be considered as binding or effective in any case except the one acted upon or as a precedent for future action in the House itself. ${ }^{60}$

Despite several efforts over the next decade, the House from Dantzler v. Lever on continued to claim that only the courts could resolve these issues. ${ }^{61}$ And, for black voters in the South, there the situation remained, more or less, until the Voting Rights Act of 1965.

60. H.R. Rep. No. 58-1740, at 3 (1904).

61. Stavis, 57 Miss. L.J. at 638-39 (cited in note 18). 


\section{IV}

Does Giles reflect the fact that "[1]aw stands impotent before history" ${ }^{\prime 2}$-or merely the human tendency, from which judges are hardly immune, to find "reality" so refractory as to provide an excuse for not doing what little might be done? Currently it has become fashionable to downplay the effectiveness of government; not surprisingly, the courts have been swept into this trend. In the age of judicial minimalism, one hardly wants to be seen as a judicial romantic, and reasons surely abound for thinking Holmes' world-weary realism might have understood his context as well as any hindsight efforts. White-supremacy political entrepreneurs in the South shared Holmes' view of the force required to stop disfranchisement, for despite acknowledging disfranchisement to be unconstitutional, they simply proclaimed "there aren't enough soldiers in the U.S. Army to make whites give up the vote." tions of "enlightened" opinion in New England, such as the Atlantic Monthly, which announced itself supportive in principle of political equality for all races, proclaimed Reconstruction enfranchisement of blacks as a "grave ... error" and "short cut to equality" that had bestowed "the sudden gift of the ballot to men wholly unprepared to use it wisely" and as a result had "proved disastrous." change in 1965, it did indeed take the concerted action of Congress, the President, and the federal courts-including sending federal officials into Southern counties to take over the registering of voters. ${ }^{65}$ Even nearly a century later, Holmes was not

62. Fiss, History of the Supreme Court of the United States at 373 (cited in note 9).

63. These are the 1898 dares of the leader of Wilmington, North Carolina's White Government League, as it pursued segregation and the disfranchisement that would soon follow via constitutional amendment in 1900 (quoted in Glenda E. Gilmore, Gender and Jim Crow: Women and the Politics of White Supremacy in North Carolina, 1896-1920 at $121(1996))$.

64. LXXXVIII, The Atlantic Monthly 433, 434, 436 (cited in note 46). Instead of nationally-compelled enfranchisement, the Atlantic encouraged trust in "the good sense of the South," agreed that disfranchisers were "doubtless right in believing that open, avowed suppression of the negro vote-if that vote is to be eliminated-is better for all concerned than a scheme of fraud and chicanery," and urged only that any franchise restrictions be applied equally to both races. Id. at 436 .

65. On the effectiveness of these officials between 1965-1970, see Davidson and Grofman, Quiet Revolution at 367-69 (cited in note 31) (in states with strong presence of such officials, Mississippi and Alabama, more than half the majority-black counties had majority-black registered electorates as early as 1967-68, while other southern states specially covered by the Voting Rights Act did not reach this marker until the mid-1980s compared to a baseline of zero such counties in 1965, on the eve of the Act). 
far off the mark in envisioning a pervasive national presence in the South as the predicate to full black political participation.

Still, there were dissenting voices, not just that of the great dissenter Justice Harlan, who indeed did so here again, but ones reflecting more widespread opinion. The New York Daily Tribune, in response to Giles, plaintively editorialized:

Somewhere, somehow, there must be a way of passing on the
constitutionality of State laws which plainly nullify the spirit
of the federal Constitution, and it is no more an assumption of
the administrative functions of a State government for the
court to declare that State authorities cannot deprive negroes
of a ballot on pretexts which do not exclude white men than it
is for the court to overrule any other action of a State or its
officers.

We will never know whether a Supreme Court opinion upholding Giles' claims (or perhaps validating them without ordering specific relief) would have influenced the politics, culture, and psychology of key individual actors in specific states, whether or not such a decision would have been legally effective or influential over national politics. But historical moments are often more contingent than they look generations down the road; paths actually taken acquire an aura of inevitability about them. No issue in American history, perhaps, generates this false sense of determinism more than that of race. The postCivil War renewal in the South of total white political domination easily seems pre-ordained and unavoidable. The "realist" strands in Holmes' opinion encourage that view in justification of one of the worst moments in the Court's history. But the political culture of disfranchisement was more fluid and precarious, in some states even more than others, than it appears in hindsight, or perhaps appeared to Holmes. Social and political historians of racial orders consistently discover the contingent and dynamic processes behind the construction of racialized social and political regimes, processes in which individual actions, cultural constraints, and institutionalized forms mutually influence and re-shape each other. ${ }^{67}$ This is more true of the constitutional

66. N.Y. Daily Tribune (April 29, 1903).

67. For the post-Civil War American South, this point is developed powerfully in Frederick Cooper, Thomas C. Holt, and Rebecca J. Scott, Beyond Slavery: Explorations of Race, Labor, and Citizenship in Post-Emancipation Societies Ch. 3 (U. of North Carolina Press, 2000); see also Lee D. Baker, From Savage to Negro: Anthropology and the Construction of Race, 1896-1954 (U. of California Press, 1998). For a few examples from other post-slavery racial orders, whose subsequent political and social systems developed 
moment at which disfranchisement went to the Supreme Court than might be thought. For once the Supreme Court effectively blessed the disfranchising constitutions, those constitutions then created an electorate in their own image. One of the most robust observations political scientists have made is that electoral structures once put into place "tend to be very stable and to resist change." $" 68$ The dramatically constricted electorates disfranchisement brought into being, with their ground rules and institutional structures locked into place at the constitutional level, managed to maintain control over southern politics, through the one-party Democratic monopoly, until national intervention forced these electoral ground rules to change in 1965. From that perspective, the triumph of disfranchisement, no matter what the Court had done in Giles, might well seem inevitable.

But when we enter into the period, or descend from the Olympian heights from which Holmes seemed to have viewed events, disfranchisement was hardly foreordained, nor is it clear that Supreme Court resistance to it would have had no effect. For one, the South was not monolithic; in Maryland, for example, disfranchisement failed, and even where it succeeded, in places like North Carolina, politics was not necessarily the same as in Mississippi or Alabama. In assessing Giles, we might therefore ask not whether a contrary Supreme Court decision would have stopped disfranchisement everywhere, but whether it might have made a difference somewhere, such as states like North Carolina. There whites were deeply divided over disfranchisement; when the disfranchising constitution of 1900-just before Giles - was submitted for popular approval, it passed with only $58.6 \%$ of the vote, with black voters almost totally excluded from the polls by violence and intimidation. ${ }^{69}$ Moreover, part of

quite differently from that in the U.S. South, of the role of choice and contingency in the construction of racial orders, see generally Ada Ferrer, Insurgent Cuba: Race, Nation, and Revolution, 1868-1898 (U. of North Carolina Press, 1999) and Thomas C. Holt, The Problem of Freedom: Race, Labor, and Politics in Jamaica and Britain, 1832-1938 (Johns Hopkins U. Press, 1992). In general, scholars of social movements also consistently emphasize how much specific moments of political vulnerability, and their successful exploitation or avoidance, influence success or failure of such movements. See, e.g., Sidney Tarrow, Power In Movement: Social Movements, Collective Action, and Mass Politics In The Modern State (Cambridge U. Press, 1994); Theda Skocpol, States and Social Revolutions (Cambridge U. Press, 1979); Charles Tilly, From Mobilization to Revolution (Addison-Wesley, 1978); Doug McAdam, Political Process and the Development of Black Insurgency, 1930-1970 (U. of Chicago Press, 1982).

68. Arend Lijphart, Democracies: Patterns of Majoritarian and Consensus Government in Twenty-One Countries 52 (Yale U. Press, 1994).

69. For the statistics, see Allison v. Sharp, 184 S.E. 27, 30 (N.C. 1936); Kousser, Southern Politics at 193 (cited in note 1). 
what also comes as a surprise to many about this entire era is the robust, interracial political coalitions that flourished in some places for a period, and North Carolina affords an important example. Far from white toleration of black political participation being inconceivable, it was the very success of interracial political coalitions that catalyzed the disfranchisement movement among the previously ruling white elite. ${ }^{70}$ In North Carolina, a fusion coalition of Republicans and Populists, with black and white political support, controlled the state legislature as late as 1894-1898. In 1896, numerous blacks were being elected to local offices, such as justices of the peace, school committeemen, aldermen, county commissioners, constables, register of deeds, and a city attorney. ${ }^{71}$ North Carolina had a well-educated, thriving black middle-class on the eve of disfranchisement; yet as a leading historian puts it, "[w]ithin a decade, the white supremacy campaign and disfranchisement had erased the image of the black middle class from the minds of white North Carolinians." Thus it is no wonder that we have little recognition of the political possibilities that were being realized in places like North Carolina just before disfranchisement. Indeed, the disfranchisement movement should be seen as testimony to this very fact; it was propelled by the aim of the Democratic Party to reseize control of state politics and to destroy the conditions that had made for partisan competition and greater participation by poor and uneducated whites as well as blacks. It is for this reason that disfranchisement was resisted by so many white voters and that the constitution barely passed in an effectively all-white electorate. The Democratic Party, the organized vehicle of white supremacy, regained control of the legislature and governor's office by framing politics around issues of race rather than economics or class. Rhetorically equating fusion rule with black political power, and with black rape of white women ("not one of our fair women has even been assaulted in this land but that the infamous act may be traced to the Fifteenth Amendment"), ${ }^{73}$ the Democratic Party sought to make its dominance enduring

70. See, e.g., Kousser, Southern Politics at 183 (cited in note 1) (until 1898, “[t]he North Carolina political system was perhaps the most democratic in the late nineteenthcentury South.").

71. Gilmore, Gender and Jim Crow at 78 (cited in note 63).

72. Id. at 143.

73. This is from the Alabama Constitutional Convention, but similar statements were widespread across Southern disfranchising states. Mcmillan, Constitutional Development in Alabama at 292 (cited in note 30) (quoting the Chairman of the Suffrage Committee, from the Official Proceedings of the 1901 Alabama Constitutional Convention); see Gilmore, Gender and Jim Crow at 85, 97 (cited in note 63). 
through constitutional revision. Thus, a few years before disfranchisement, North Carolina experienced robust interracial parties and politics; disfranchisement itself barely succeeded. Given how fluid politics was in this period, would nothing have changed in the fragile political dynamics of North Carolina had the Supreme Court found disfranchisement a blatant constitutional violation? Once enacted, the North Carolina literacy test endured; it survived later constitutional challenges in the state supreme court in $1936^{74}$ (actually, was affirmatively celebrated there) and the U.S. Supreme Court in $1959,{ }^{75}$ before the Voting Rights Act eventually eliminated it.

In assessing Giles, therefore, one must ask whether Holmes was as "realistic" about North Carolina as he perhaps was about Alabama, Giles's home state. But now here is the rub: Alabama was not Alabama either. For white Alabama, too, was not a monolithic state determined to destroy the Fifteenth Amendment at all costs, no matter what the Supreme Court did. Far from it: The Alabama Constitution of 1901 that Giles challenged might well not even have been approved in the referendum that nominally endorsed it. Like many Southern states, Alabama's politics were sharply divided between Black-Belt counties, where blacks constituted a large part or majority of the population, and the "hill counties," areas with few blacks, never suited for plantation economies, often mountainous and made up of small farmers. Much of Alabama's history consisted of struggles for political domination between northern Alabama and the

74. See Allison v. Sharp, 184 S.E. 27,30 (N.C. 1936). Citing statistics on black and white educational systems, the North Carolina Supreme Court considered that it "would not be amiss to say that this constitutional amendment providing for an educational test ... brought light out of darkness as to education for all the people of the state. Religious, educational, and material uplift went forward by leaps and bounds." Some historians argue that this statement is not as fatuous as one might think; on this interpretation, the white supremacist Democratic Governor during disfranchisement, Charles Aycock, saw universal education as "the South's salvation" and successfully used the test's existence to press for greater public investment in education, including in black schools, though of course not in equal proportion. Gilmore, Gender and Jim Crow: Women and the Politics of White Supremacy in North Carolina, 1896-1920 at 121-22, 158 (cited in note 63). Other historians, relying on detailed quantitative analysis, argue that while the absolute levels of public educational expenditures increased dramatically, there was a substantial increase in the relative inequality between blacks and whites in public burdens and benefits, including education, after disfranchisement in North Carolina. See $J$. Morgan Kousser, Progressivism-For Middle-Class Whites Only: North Carolina Education, 1880-1910, XIVI J. So. Hist. 169, 191-92 (1980) ("Most strikingly, blacks suffered much more discrimination after than before disfranchisement and the establishment of the one-party system, particularly in the heavily black areas where before 1900 their votes had bought a disproportionately high level of services.").

75. Lassiter v. Northampton County Bd. of Elections, 360 U.S. 45 (1959). 
Black-Belt counties in south central Alabama. ${ }^{76}$ The disfranchising constitution was approved with only $57 \%$ of the vote (a margin of 26,879 votes), and the total vote was against it in 54 of

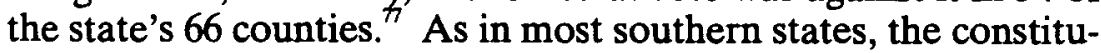
tion was a product, not of a united white majority, but of a faction of conservative Democratic Party elites; they were resisted tooth and nail by Republicans, remaining Populists, and Democrats who favored more popular control over politics. The constitution prevailed because it was approved 36,224 to 5,471 in 12 late-reporting Black-Belt counties; yet in some of these counties, there were three times as many votes for the constitution as white men eligible to vote. As the leading study of this referendum concludes, unless blacks voted overwhelmingly to disfranchise themselves, these counties almost certainly engaged in the familiar practice of "counting in" the black vote: "almost every eligible Negro was 'voted' although thousands never appeared at the polls." Holmes, confident he understood the ways of the world even in his first few months on the Court, was simply wrong that the Alabama Constitution of 1901 reflected the fact, let alone the unalterable fact, that "the great mass of the white population intends to keep the blacks from voting." Whether that was so or not, the constitution Holmes was asked to judge hardly provided conclusive evidence of that "realistic" fact.

One should be neither naive nor anachronistic, of course, about the Court's power. ${ }^{79}$ But once again, when we enter this

76. See Thomton, Politics and Power at 27, 40-41 (cited in note 35).

77. The information in this paragraph comes from Mcmillan, Constitutional Development in Alabama at 350-52 (cited in note 30).

78. Id. at 351.

79. In a major study of the Supreme Court during the era of segregation and disfranchisement, Michael Klarman argues both that "it may be implausible to think that the Justices realistically could have reached different results in cases [like Giles]," given dominant public opinion and racial attitudes, and that even had the Court come out differently, "it remains unlikely that much would have changed in practice for Southern blacks." Michael J. Klarman, The Plessy Era, 1998 S. Ct. Rev. 303, 303, 414; see generally Michael J. Klarman, Race and the Court in the Progressive Era, 51 Vand. L. Rev. 881 (1998). I cannot here give an adequate response to Klarman's detailed and important corrective to overly simplistic condemnation of the Court; in any event, for many purposes, I consider discussion of the issues Giles raises more important than counterfactual analysis of whether a contrary decision would or would not have "mattered." But I do think Klarman writes about "public opinion" at a more general, distant, and universal level than many of the cultural and political historians who have studied the construction of racial identity and politics, in the Plessy-era South as well as elsewhere. See, e.g., supra notes $1,16,18,22,26,28,55,63,67$. In general, these works suggest to me that public opinion, on race as on other matters, is rarely uniform among a monolithic white majority; that public opinion is typically malleable to a surprising extent and is often manipulated by political actors for various purposes, particularly partisan ones, as public-opinion scholars consistently document, see, e.g., Donald R. Kinder and Lynn M. Sanders, Di- 
period enough to recognize how fluid it was, and how divided even the white electorate was, it is hard to be as complacent as Justice Holmes about how little cultural effect, in some places at least, a Supreme Court decision condemning disfranchisement might have had. Moreover, from the perspective of the Court itself, Justice Frankfurter, an heir to Holmes in more than just Holmes' formal seat, long argued that the Court's legitimacy would be compromised should it enter "the political thicket" and decide cases involving systemic political claims. Yet when the Court did so in Baker v. Carr, over Frankfurter's vehement objections, its one-vote, one-person decisions requiring the restructuring of nearly every state legislature in the country seemed to enhance, not compromise, the Court's stature.

\section{V}

Giles is probably the most momentous ignored decision in the history of the Supreme Court. Even within the specific confines of the disfranchisement struggle, Giles not only opens a constitutional window into this too little understood period of American law and history. For Giles also poses in their most primordial form questions of the relationship among law, politics, and culture, as well as the relationship of national to state power in the fundamental sphere of democracy itself. The decision also provides perspective on how much different the Court's proclaimed self-conception of the nature and effectiveness of judicial power was in the pre-Brown era. For some, this will perhaps reveal little more than judicial hypocrisy, for the Giles era

vided By Color (U. of Chicago Press, 1996); that institutions and laws matter in shaping politics and cultures at least as much as purportedly pre-existent and fixed cultural attitudes; that to the Southern elite in control of disfranchisement, it certainly mattered that they achieve domination within legally accepted forms; and that given the fluidity of cultural constructions of race and the key role of institutions and laws, the processes described here were far more contingent than more deterministic analysis suggests, and that interventions of one sort or another, including Supreme Court decisions, can influence subsequent events both legally and culturally -in some places more than others, at some times more than others - more than may be readily apparent from too distant a perspective. Even at the start of the Civil War, it might well have seemed inconceivable that national policy would soon require uncompensated emancipation of all slaves in the Confederate States; but as at least a decade of scholarship now shows, dynamic social processes the War unleashed, particularly the actions of slaves, such as fleeing to Union troop lines, consistently created new pressures and demands that altered the context and made implausible any settlement short of universal abolition-no matter how resolute public opinion and national policy might have seemed against that outcome a mere four years earlier. For a brief summary of this voluminous work, see generally Ira Berlin, et. al., Slaves No More: Three Essays on Emancipation and the Civil War (Cambridge U. Press, 1992). 
was after all also the era of Lochner; the Court majority surely had no difficulty in regularly striking down majoritarian regulation of wages, hours, and conditions of work, even if those decisions provoked dissents from Holmes himself. But for others, the nature of the political stakes in Giles, and the kind of active judicial monitoring and oversight of ongoing state electoral practices that a favorable ruling might have required, could justify a judicial view that Giles posed a singularly formidable challenge-even if post-Brown courts would be relatively more assured about their capacity to respond. Conflicts between capital and labor, in the United States at least, have never produced a Civil War.

But beyond the immediate issues surrounding disfranchisement, Giles also played a broader role in constructing the category of "political rights" and locating it beyond the reach of constitutional law. As Justice Frankfurter's invocation of Giles shows almost half a century later, to deny judicial power to address grossly malapportioned Congressional districts and state legislatures, ${ }^{80}$ Giles had doctrinal and institutional ramifications even beyond the profound issue of black disfranchisement. From Holmes to Frankfurter and beyond, Giles reflected and shaped a constitutional culture in which the large issues of democratic governance and institutional structure were, like unknown territories on a medieval map, cast as threatening monsters and placed outside the known domains of constitutional law. ${ }^{81}$

80. Colegrove v. Green, 328 U.S. 549 (1946).

81. For reliance upon Giles in the state courts, see, e.g., State v. Albritton, 37 So.2d 640 (Ala. 1948) (holding that courts of equity have no power to intervene in political affairs); Boswell v. Bethea, 5 So. 2d 816 (Ala. 1942) (refusing to review claim of racially discriminatory voter registration); Wilkinson v. Henry, 128 So. 362 (Ala. 1930) (holding that party rules regulating participation in primaries are not justiciable); Walls v. Brundidge, 160 S.W. 230, 232 (Ark. 1913) (holding challenge non-justiciable to claims of fraud in Democratic primary because rights involving voting were are political rights). For similar reliance in the federal courts, see Caven v. Clark, 78 F. Supp. 295, 301 (W.D. Ark. 1948) ("In the light of the language of the Supreme Court which we have heretofore quoted from its opinion in Colegrove $v$. Green ... it certainly cannot be said that that Court, by whose decisions we are of course bound, has in any sense strayed from the rule announced by it in Giles v. Harris ... forty-five years ago.") (denying jurisdiction in equity for claim that defendants and thousands of others had their poll taxes unlawfully paid and thereby unlawfully obtained receipts for poll taxes enabling them to vote in primary election); Blackman v. Stone, 17 F. Supp. 102 (S.D. Ill. 1936), vacated for mootness 300 U.S. 641 (1937) (denying jurisdiction for suit seeking to have certain names placed on ballot for state-wide elections); Grigsby v. Harris, 27 F.2d 942 (S.D. Tex. 1928) (Democratic Party's exclusion of black voters from primaries non-justiciable under Giles) (effectively reversed in Nixon v. Condon, 286 U.S. 73 (1932)). 
Baker v. Carr began to change that, but not as much as some might think. Doctrinally, courts have indeed entered the political thicket and found the Constitution to invalidate particular means by which politically dominant actors have tried to "lock up" political institutions through techniques analogous to those used in the era of disfranchisement. ${ }^{82}$ But even so, Giles has continued to exert unrecognized gravitational pull over current doctrine. For Giles had established, and Colegrove had confirmed, that courts would not address systemic political wrongs. In part to avoid these principles, the Court in the Baker v. Carr era therefore channeled such claims into an individual rights framework, where they could be addressed through conventional rights-oriented constitutional doctrine. ${ }^{83}$ But forcing questions about the systemic organization of democratic politics into this rights model has encouraged the Court to fail to engage the inevitably systemic nature of these issues. ${ }^{84}$

Moreover, judicial application of constitutional law to issues of democratic political organization has been tentative, hesitant, erratic, and lacking in sustained commitment or conviction. ${ }^{85}$ That this reflects, in part, the longer constitutional tradition in which issues of democratic governance were off the map altogether seems likely. Even today, the canon of constitutional law barely touches upon issues of democratic governance, let alone giving those issues the systematic, sustained, and central attention they require. Giles itself, as I documented at the outset, remains largely obscure. Recovering the history of constitutional law's relationship to America's long running anti-democratic structures before the Voting Rights Act is one way of beginning to place democracy front and center in constitutional law and thought. The kind of democracy we experience is not the pure distillation of organic cultural and political forces. Democratic experience is a product, in part at least, of the institutional structures and legal rule-structure, including constitutional law, that can constrain or liberate the kind of democracy we have.

82. See generally Samuel Issacharoff and Richard H. Pildes, Politics as Markets: Partisan Lockups of the Democratic Process, 50 Stan. L. Rev. 643 (1998) and the articles discussing the problem and theory of political lockups in the Virginia Law Review Symposium entitled The Law and Economics of Elections, 85 U. Va. L. Rev. 1533, 1533-1812 (1999).

83. I am indebted to Sam Issacharoff for this provocative insight, which I credit to him in the event that further reflection leads me to conclude it is wrong.

84. For elaboration, see Richard H. Pildes, The Theory of Political Competition, 85 U. Va. L. Rev. 1605 (1999).

85. For more on this indictment, see generally Samuel Issacharoff and Richard $\mathbf{H}$. Pildes, Not By "Election Law" Alone, 32 Loy. L.A. L. Rev. 1173 (1999). 